\title{
Occurrence of CCA-treated timber in caterers' fuelwood stocks in the Cape Town region
}

AUTHORS:

Rissa Niyobuhungiro ${ }^{\top}$

Sivapregasen Naidoo $0^{1,2}$

Aqiel Dalvie $^{2}$

Harro von Blottnitz ${ }^{1}$

\section{AFFILIATIONS:}

${ }^{1}$ Environmental and Process Systems Engineering, Department of Chemical

Engineering, University of Cape Town, Cape Town, South Africa

${ }^{2}$ Centre for Occupational and Environmental Health Research, Department of Occupational Health and Family Medicine, University of Cape Town, Cape Town, South Africa

\section{CORRESPONDENCE TO:}

Harro von Blottnitz

\section{EMAIL:}

harro.vonblottnitz@uct.ac.za

\section{POSTAL ADDRESS:}

Department of Chemical

Engineering, University of

Cape Town, Private Bag X3,

Rondebosch 7701, South Africa

\section{DATES:}

Received: 16 Nov. 2011

Revised: 12 June 2012

Accepted: 20 July 2012

\section{KEYWORDS:}

CCA; microwave digestion; wood fuel; informal economy; catering

\section{HOW TO CITE:}

Niyobuhungiro R, Naidoo $\mathrm{S}$, Dalvie A, Von Blottnitz H. Occurrence of CCA-treated timber in caterers' fuelwood stocks in the Cape Town region. S Afr J Sci. 2013;109(1/2), Art \#1015, 5 pages. http://dx.doi. org/10.1590/sajs.2013/1015

(c) 2013. The Authors.

Published under a Creative Commons Attribution Licence.
Wood used as fuel under conditions of urban poverty is a source of air pollution. Fuelwood is harvested from peri-urban green areas or sourced as waste from industry or commerce, and used in the informal economy, both by households and by productive activities such as roadside catering. End-of-life timber may have previously been treated for protection, sometimes by impregnation with chromated copper arsenate (CCA). Combustion of CCA-treated timber could magnify the health and environmental risks associated with air pollution, as a result of the release of arsenic and chromium in toxic and carcinogenic forms. Fuelwood supplies of roadside caterers in the urban settlements of Nyanga and Khayelitsha were randomly sampled and 86 collected specimens were prepared for analysis. A further 12 samples were taken, based on their appearance, from households and caterers in settlements near Stellenbosch, Worcester and Paarl. Shavings from the timber specimens were microwave digested using nitric acid and analysed using inductively coupled plasma analysis. All samples collected in the first round showed low concentrations of $\mathrm{Cr}$, $\mathrm{Cu}$ and $\mathrm{As}$, believed to be representative of natural backgrounds. Of the 12 peri-urban samples collected in the second round, 8 showed higher levels, typical of treatment to $\mathrm{H} 2-\mathrm{H} 5$ standards. Once it was clear that appearance was a fair indicator of treatment, a further set of 18 suspect pieces from caterers' supplies in Langa, Nyanga, Khayelitsha and Kayamandi were tested, of which at least 1 sample from each area was found to be treated. CCA-treated timber was found infrequently in fuel supplies of urban caterers, and more frequently in periurban areas. Further research and interventions to limit health and environmental risks are recommended.

\section{Introduction}

Energy poverty remains a challenge in developing countries, impacting on the environment, health, security and well-being of an estimated 3 billion people. Around 2.64 billion people (or $40 \%$ of the world's population) lack modern fuels for cooking and heating while 1.6 billion have no access to electricity; three-quarters of these people live in rural areas. ${ }^{1}$

In Cape Town, an estimated 142000 tonnes of wood is used annually in informal settlements for thermal purposes such as heating and cooking'; a sizeable fraction of this amount represents waste timber. Informed by Nissing's interviews with timber users and suppliers, ${ }^{3}$ we suspected that an unknown proportion of the wood used by informally operating caterers in townships and informal settlements in Cape Town had been treated with a preservative consisting of chromated copper arsenate (CCA), or Tanalith ${ }^{\circledR}$ as it is known by local industry. Inorganic arsenic, one of the constituents of CCA, is a known poison that is lethal at just $70-200 \mathrm{mg} .{ }^{4}$ Inorganic arsenic is also a known carcinogen at lower doses and is associated with a number of non-cancerous long-term health effects including effects on the skin and on vascular, respiratory and gastro-intestinal systems, as well as neurotoxic effects. Chromium (VI) is also a carcinogen; non-cancer chronic health effects of chromium exposure include respiratory and dermal effects. ${ }^{5}$ Excess copper is associated long term with respiratory effects and damage to red blood cells. ${ }^{6}$ Exposure to these metals can occur through the inhalation of fumes and fine ash released from treated wood during combustion, contact with the wood and/or ash and intake of contaminated food or liquids. Emerging medical studies have indicated that inorganic arsenic (As) is not only a potent human carcinogen itself, but also that exposure to even very small amounts of arsenic causes existing human cancer tumours to grow more rapidly and aggressively. ${ }^{7}$

The South African Bureau of Standards (SABS) has set South African National Standards for different categories of wood to ensure wood remains protected against parasites and is thus suitable for intended applications over long periods of time. The minimum CCA levels required to preserve timber for 20 years are shown in Table 1.

Table 1: Wood preservation categories, dose of chromated copper arsenate (CCA) and application

\begin{tabular}{|l|l|l|}
\hline \hline $\begin{array}{l}\text { Wood } \\
\text { category }\end{array}$ & $\begin{array}{l}\text { Dose of } \\
\text { CCA }\end{array}$ & Application \\
\hline \hline Hoi & $\begin{array}{l}\text { None (only } \\
\text { insecticide) }\end{array}$ & Insecticide protection for specific purpose internal joinery (mouldings, ceilings, flooring) \\
\hline H2 & $6 \mathrm{~kg} / \mathrm{m}^{3}$ & Internal use (frames, roof trusses and ceilings) \\
\hline H3 & $8 \mathrm{~kg} / \mathrm{m}^{3}$ & $\begin{array}{l}\text { Exterior above-ground use (garden furniture, balustrades, gates and weather } \\
\text { boards) - moderate hazard }\end{array}$ \\
\hline H4 & $12 \mathrm{~kg} / \mathrm{m}^{3}$ & Ground contact (fencing, pergolas, carports, bridges and flower boxes) - high hazard \\
\hline H5 & $16 \mathrm{~kg} / \mathrm{m}^{3}$ & Freshwater contact (piling, jetties, retaining walls and walkways) - high hazard \\
\hline H6 & $24 \mathrm{~kg} / \mathrm{m}^{3}$ & Seawater contact (piling, jetties, slipways, retaining walls) - high hazard \\
\hline
\end{tabular}


A pale darkish green colour is left on wood freshly treated with CCA, depending on the type of the wood used and the age of the wood. ${ }^{8}$ At the end of its intended use, such wood waste may, however, become indistinguishable from untreated or differently treated wood.

In North America, Europe and Australia, the timber preservatives used include CCA, acid copper, ammoniacal copper arsenate, chromated zinc chloride, copper azole and ammoniacal copper zinc arsenate. ${ }^{9,10}$ Three types of CCA (A, B and C), which vary in their amounts of chromium (Cr), copper (Cu) and arsenic (As), are used globally (Table 2), with type $C$ being most common in the USA and worldwide. ${ }^{11}$

Table 2: $\quad$ Cr: Cu: As ratios in different chromated copper arsenate (CCA) types used internationally

\begin{tabular}{|c|c|c|c|c|}
\hline Type & $\begin{array}{l}\mathrm{CrO}_{3} \\
(\%)\end{array}$ & CuO (\%) & $\begin{array}{l}\mathrm{As}_{2} \mathrm{O}_{5} \\
(\%)\end{array}$ & $\begin{array}{l}\text { Cr: Cu: As } \\
\text { ratio }\end{array}$ \\
\hline CCA-A & 65 & 18 & 17 & 2.4: 1: 0.8 \\
\hline CCA-B & 35 & 20 & 45 & 1.1: 1: 1.8 \\
\hline CCA-C & 47.5 & 18.5 & 34 & $1.7: 1: 1.5$ \\
\hline Tanalith & & & & 1.5: 1: 1.4 \\
\hline
\end{tabular}

In this paper, we report on a fuelwood sampling and analysis campaign undertaken in specific urban and peri-urban parts of Cape Town, in order to assess whether there might be thus far unrecognised health concerns, specifically related to occupational exposure by informally operating roadside caterers. No study investigating $\mathrm{Cr}$, $\mathrm{Cu}$ and $\mathrm{As}$ in fuelwood has previously been published in South Africa. Occupational health concerns in the extensive and growing informal sector of the economy are also systematically under-researched. All international publications on environmental and health impacts of CCA-treated timber are in the context of a formal economy. ${ }^{9,11-14}$

\section{Methods and materials}

\section{Sampling}

Informally operating caterers usually buy their fuelwood from suppliers. Caterers need fuelwood to braai meat, boil chicken and sheep heads, and to prepare African beer. Various types of wood are used. Food preparation methods that put the smoke into direct contact with the food, especially braai-ing, generally rely on harvested timber, reportedly because using treated timber has a negative impact on the taste. ${ }^{3}$ Waste timber is more often found in the supplies of caterers who boil their products; this timber sometimes has a distinct green tint that makes it easily identifiable as probably CCA-treated.

We collected wood samples in three Cape Town townships. - Langa, Nyanga and Khayelitsha - and three townships of the Cape Winelands - Zwelethemba (Worcester), Mbekweni (Paarl) and Kayamandi (Stellenbosch) - during three different campaigns.

In the first campaign, a member of the research team visited Nyanga and Khayelitsha in October 2010 and randomly collected wood samples destined to be used as a fuel source by informally operating caterers. Some 250 samples were taken, from the top, middle and bottom of fuelwood stockpiles. Of these collected samples, 55 from Nyanga and 31 from Khayelitsha were randomly selected for further laboratory analysis as per the methods discussed below.

In February 2011, a ground pole with a dark green tint was noticed in a fuelwood stockpile in Kayamandi (Stellenbosch). The discovery of this suspicious looking specimen made us think of a second campaign in peri-urban areas. The second campaign started in March 2011, making use of purposive spot sampling, taking only fuelwood samples for laboratory analysis if they appeared to have been CCA-treated. A total of 11 samples was collected from Zwelethemba (Worcester) and Mbekweni (Paarl), both from houses and from caterers' fuelwood trolleys. The samples were planks, four of which showed the characteristic green colour, and were stored separately. The Stellenbosch specimen was combined with these 11 samples as being representative of suspect fuelwood from a peri-urban area.

Once analysis of samples from the first two campaigns was completed, we conducted a third sampling campaign in both urban and peri-urban areas. In June 2011, 18 samples were purposefully collected based on their suspicious appearance, from most of the areas sampled before. Worcester and Mbekweni were not revisited but Langa was also sampled as an urban area. In each case, all samples were labelled to record where they were collected from. In all the study areas the residents and caterers were asked what type of wood they use, what they use it for and from where they source the wood

To develop a better understanding of CCA timber treatment, we visited the factory of Timber Preservation Services (TPS) in Epping Industria. An indicative concentration of CCA solution applied to wood was obtained from the TPS Manager (on 5 February 2011): $140.2 \mathrm{~g} / \mathrm{kg}$, $91.8 \mathrm{~g} / \mathrm{kg}$ and $135.3 \mathrm{~g} / \mathrm{kg}$ of $\mathrm{Cr}$, Cu and As, respectively. The $\mathrm{Cr}$, Cu and As concentrations in wood after Tanalith impregnation could thus be estimated, as presented in Table 3, for each of the standardised treatments (shown in Table 1); the density of the wood was assumed to be $900 \mathrm{~kg} / \mathrm{m}^{3}$.

Table 3: Estimated compositions of Tanalith-impregnated timber

\begin{tabular}{|l|l|l|l|}
\hline \hline $\begin{array}{l}\text { Wood } \\
\text { category }\end{array}$ & Cr (mg/kg) & Cu (mg/kg) & As $(\mathrm{mg} / \mathrm{kg})$ \\
\hline \hline H2 & 935 & 612 & 902 \\
\hline H3 & 1246 & 816 & 1203 \\
\hline H4 & 1869 & 1224 & 1804 \\
\hline H5 & 2492 & 1632 & 2405 \\
\hline H6 & 3739 & 2448 & 3608 \\
\hline
\end{tabular}

It was noted that the Tanalith Cr:Cu:As ratio (1.5: 1:1.4) is in agreement with what was reported, ${ }^{13}$ as nominal values of $3120 \mathrm{mg} / \mathrm{kg}, 1840 \mathrm{mg} / \mathrm{kg}$ and $2800 \mathrm{mg} / \mathrm{kg}$ of $\mathrm{Cr}$, Cu and As, respectively. The ratio corresponding to these nominal values is $1.6: 1: 1.5$. Both ratios are similar to that of CCA type C (1.7: 1: 1.5), as shown in Table 2.

\section{Sample preparation and laboratory analysis}

Care needs to be taken when working with CCA-treated timber. Gloves were worn whenever suspect timber samples were handled, and dust masks and extraction facilities were used when working with fine powders.

To prepare analysis samples from collected fuelwood specimens, it was necessary to obtain a representative chip sample up to a depth of $40 \mathrm{~mm}$. Samples were repeatedly bored using a drill press equipped with a 15-mm-diameter jagged tooth bit (or hole saw). The area covered was $100 \times 100 \mathrm{~mm}$, whenever possible, allowing for about 45 holes to be bored; if a specimen was too small to accommodate this area, the entire surface was bored. The collected chips were then milled to a free-flowing powder form with $100 \%$ less than $0.25 \mathrm{~mm}$ using a ball mill. All the sawdust samples were kept in clean plastic bags and labelled accordingly.

The moisture content of the samples was determined using an OHAUS MB45 Moisture Analyzer (Ahaus Corporation, Pine Brook, NJ, USA). All metal concentrations reported here are on a dry-weight basis.

An amount of $0.25 \mathrm{~g}$ of each sample was microwave digested in $10 \mathrm{~mL}$ of $55 \%$ nitric acid according to EPA Method $3051 .{ }^{13}$ The mixture was 
then diluted to $25 \mathrm{~mL}$ with ultrapure water. A MARS Xpress closed vessel microwave digestion system (CEM Corporation, Matthews, NC, USA) was used to digest the wood samples. The system consists of a compact terminal touch screen display with operator selectable 0-1600 W output, temperature control up to $240{ }^{\circ} \mathrm{C}$, pressure control up to $800 \mathrm{psi}(5500 \mathrm{kPa})$, a layer-PTFE coated microwave cavity, HPR/ 1000/10S rotator and twelve 100-mL Teflon vessels. The conditions during digestion are shown in Table 4.

Table 4: Conditions during the microwave wood digestion procedure used in this study

\begin{tabular}{|l|l|l|l|l|}
\hline \hline Step & $\begin{array}{l}\text { Time } \\
(\mathbf{m i n})\end{array}$ & $\begin{array}{l}\text { Power } \\
\mathbf{( W )}\end{array}$ & $\begin{array}{l}\text { Temperature } \\
(\mathbf{(} \mathbf{C})\end{array}$ & $\begin{array}{l}\text { Pressure } \\
(\mathbf{k P a})\end{array}$ \\
\hline \hline Ramping time & 15 & 1600 & 192 & 1379.0 \\
\hline Holding time & 30 & 1600 & 204 & 2716.5 \\
\hline
\end{tabular}

As a result of the large number of samples necessitating prior use, the vessels were soaked in a mixture of nitric acid and hydrochloric acid overnight to prevent contamination and then rinsed with ultrapure water at least three times.

All the samples were successfully digested and the resulting solutions appeared light green. After cooling to room temperature, the sample digests were transferred to $25-\mathrm{mL}$ flasks and diluted to the final volume using ultrapure water, whilst shaking lightly. After shaking, the green colour disappeared and the samples became light and clear. This dilution was performed in a fume cupboard. The samples were then refrigerated at $4{ }^{\circ} \mathrm{C}$ until analysis. Analysis was by inductively coupled plasma (ICP) spectrometry to determine total concentrations of $\mathrm{Cr}$, $\mathrm{Cu}$ and $\mathrm{As}$.

\section{Metal analysis}

The analyses were performed with a VARIAN 730-ES ICP Optical Emission Spectrometer (Varian, Mulgrave, Australia). In all experiments, reagents blanks were taken separately. Commercially available standards were used as indicated in the results.

\section{Results}

Levels of CCA in the samples collected in the first sampling campaign in Nyanga and Khayelitsha were all well below $5 \mathrm{ppm}$ in the digestate, or $500 \mathrm{mg} / \mathrm{kg}$ in the analysed wood. The elements of concern, namely $\mathrm{Cr}$, $\mathrm{Cu}$ and $\mathrm{As}$, seemed to be present in most of these samples, at mean values of $13.4 \pm 13.5 \mathrm{mg} / \mathrm{kg}, 5.3 \pm 5.1 \mathrm{mg} / \mathrm{kg}$ and $7.0 \pm 3.5 \mathrm{mg} / \mathrm{kg}$, respectively. These levels are 10-100 times lower than those typical of the lowest dosage of CCA-treated timber ( $\mathrm{H} 2)$.

Upon advice from the treatment plants, we decided to attempt a second sampling campaign, armed now with knowledge that treated wood was of a specific functional design and showed a green tint. During the second and third round of sampling, CCA-treated timber was found, supporting the need to use visual inspection during sampling.

Of the total of 12 timber specimens sampled during the second round, 8 were CCA-positive (Figure 1), including the sample from Stellenbosch, 5 of 8 samples from Worcester and 2 of 3 samples from Paarl. The minimum, mean and maximum metal levels (in $\mathrm{mg} / \mathrm{kg}$ of dry wood) in these eight samples identified as treated were:

- Cr: 520; 2060; 6620

- Cu: 350; 910; 1940

- As: $510 ; 1520 ; 3600$

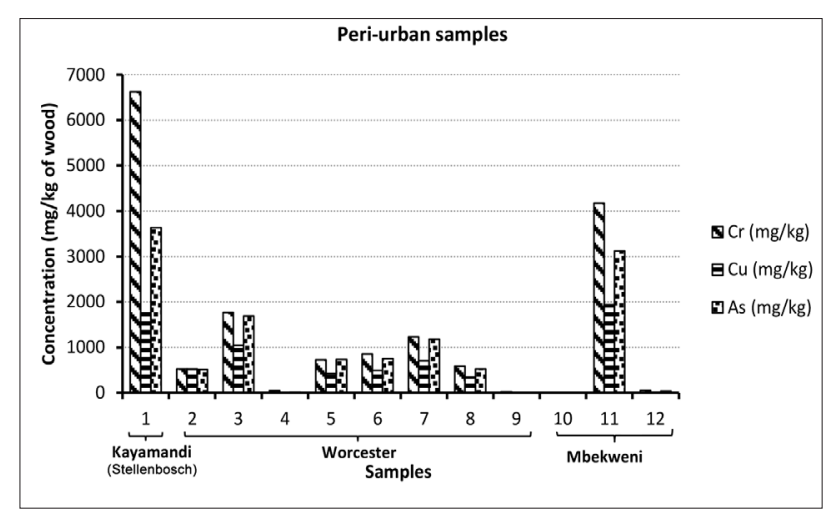

Figure 1: $\mathrm{Cr}$, Cu and As concentrations in samples selected in peri-urban areas during the second sampling campaign

Of the 18 samples collected during the third campaign, 8 contained $\mathrm{Cr}$, Cu and As (Figure 2) at levels typical of treatment, including 2 of 6 samples from Nyanga, 2 of 3 samples from Khayelitsha, 1 of 5 samples from Langa and 3 of 4 samples from Stellenbosch. The mean $\mathrm{Cr}$, $\mathrm{Cu}$ and As levels of these eight samples were very similar to those of the eight positively identified samples of the second campaign, at $2205 \pm 994 \mathrm{mg} / \mathrm{kg}, 944 \pm 372 \mathrm{mg} / \mathrm{kg}$ and $1782 \pm 770 \mathrm{mg} / \mathrm{kg}$, respectively. These results are lower on average, and more widely distributed, than the values of $2714 \pm 62 \mathrm{mg} / \mathrm{kg}, 1557 \pm 44 \mathrm{mg} / \mathrm{kg}$ and $2654 \pm 26 \mathrm{mg} / \mathrm{kg}$ reported for $\mathrm{Cr}$, Cu and As, respectively, on playground wood samples. ${ }^{13}$

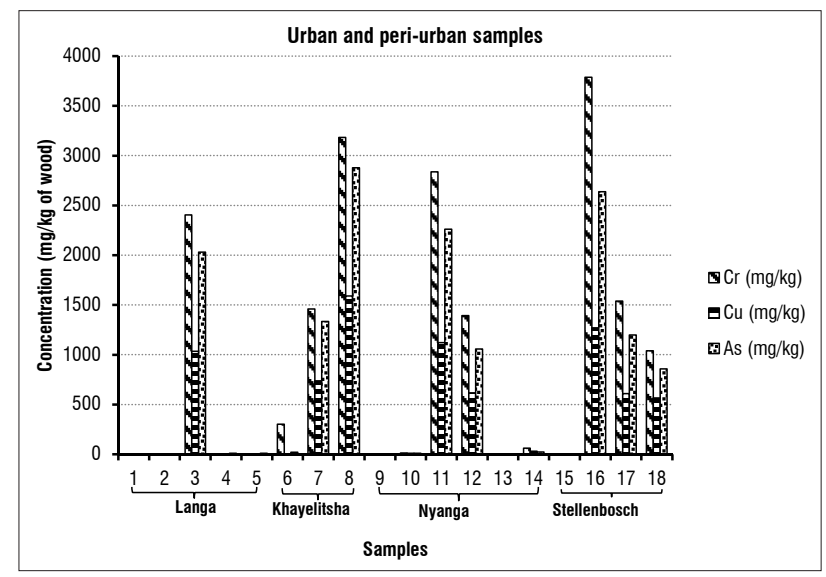

Figure 2: $\quad \mathrm{Cr}$, $\mathrm{Cu}$ and As concentrations in samples selected in urban and peri-urban areas during the third sampling campaign

Table 5 presents a summary of the results for all three sampling campaigns. A statistical interpretation should not be undertaken as the initial sampling campaign was randomly performed without the knowledge of green tinted timber as a visual indicator of CCA presence, whilst in the second and third campaigns only samples that appeared suspect were taken.

Table 6 gives an indication of the categories of CCA-treated wood into which the 16 samples found to be treated fall, based on the $\mathrm{Cr}$, $\mathrm{Cu}$ and As concentrations measured. Six samples were within the $\mathrm{H} 2$ category (37.5\%), three within H3 (18.7\%), three within H4 (18.7\%) and four displayed levels typical of $\mathrm{H} 5$ treatment (25\%). Three of four samples in the $\mathrm{H} 5$ category $(75 \%)$ and one of three in the $\mathrm{H} 4$ category $(33 \%)$ were from peri-urban areas.

Based on the $\mathrm{Cr}: \mathrm{Cu}$ :As ratios determined, it appears that the majority of the 16 samples identified as treated had been subjected to a Tanalith or CCA type $\mathrm{C}$ treatment. 
Table 5: Summary of samples and number of chromated copper arsenate (CCA)-treated samples in the study

\begin{tabular}{|l|l|l|l|l|l|l|l|l|}
\hline \hline \multirow{2}{*}{ Campaign } & \multicolumn{2}{l|}{ Urban areas } & \multicolumn{2}{l|}{ Peri-urban areas } & $\begin{array}{l}\text { Total number of } \\
\text { samples }\end{array}$ & $\begin{array}{l}\text { Number of } \\
\text { CCA-treated } \\
\text { samples }\end{array}$ \\
\cline { 2 - 9 } & Nyanga & Khayelitsha & Langa & Stellenbosch & Mbekweni & Worcester \\
\hline \hline $\begin{array}{l}\text { First campaign } \\
\text { (November 2010) }\end{array}$ & 55 & 31 & 0 & 0 & 0 & 0 & 86 & 0 \\
\hline $\begin{array}{l}\text { Second campaign } \\
\text { (March 2011) }\end{array}$ & 0 & 0 & 0 & $1(1)$ & $3(2)$ & $8(5)$ & 12 & 8 \\
\hline $\begin{array}{l}\text { Third campaign } \\
\text { (June 2011) }\end{array}$ & $6(2)$ & $3(2)$ & $5(1)$ & $4(3)$ & 0 & 0 & 18 & 8 \\
\hline Total & $61(2)$ & $34(2)$ & $5(1)$ & $5(4)$ & $3(2)$ & $8(5)$ & 116 & 16 \\
\hline
\end{tabular}

The number of samples classified as CCA-treated per site is shown in brackets.

Table 6: Summary of $\mathrm{Cr}$, Cu and As levels, likely treatment categories and recipes of all chromated copper arsenate (CCA)-treated fuelwood specimens found

\begin{tabular}{|l|l|l|l|l|l|l|l|}
\hline \hline Location & Area & Cr $(\mathbf{m g} / \mathbf{k g})$ & Cu $(\mathbf{m g} / \mathbf{k g})$ & As $(\mathbf{m g} / \mathbf{k g})$ & Hazard class & Cr: Cu: As ratio & Recipe \\
\hline \hline Peri-urban & Kayamandi & 6624 & 1761 & 3633 & H5/H6 & $3.7: 1: 2$ & unknown \\
\hline & Kayamandi & 3787 & 1270 & 2637 & H5 & $3.0: 1: 2$ & unknown \\
\hline & Kayamandi & 1539 & 609 & 1199 & H3 & $2.5: 1: 2$ & unknown \\
\hline & Kayamandi & 1039 & 567 & 858 & H2 & $1.8: 1: 1.5$ & CCA-C \\
\hline & Zwelethemba & 523 & 525 & 513 & H2 & $1.0: 1.0: 1$ & unknown \\
\hline & Zwelethemba & 1769 & 1045 & 1691 & H4 & $1.7: 1: 1.6$ & CCA-C \\
\hline & Zwelethemba & 726 & 425 & 731 & H2 & $1.6: 1: 1.7$ & CCA-C \\
\hline & Zwelethemba & 857 & 488 & 748 & H2 & $1.8: 1: 1.5$ & CCA-C \\
\hline & Zwelethemba & 1227 & 702 & 1183 & H3 & $1.7: 1: 1.7$ & CCA-C \\
\hline & Zwelethemba & 587 & 349 & 528 & H2 & $1.7: 1: 1.5$ & CCA-C \\
\hline & Mbekweni & 4178 & 1944 & 3121 & H5 & $2.1: 1: 1.6$ & CCA-C \\
\hline & Langa & 2405 & 1035 & 2031 & H4 & $2.3: 1: 1.9$ & unknown \\
\hline & Khayelitsha & 1459 & 738 & 1334 & H3 & $1.9: 1: 1.8$ & CCA-C \\
\hline & Khayelitsha & 3184 & 1590 & 2879 & H5 & $2.0: 1: 1.8$ & CCA-C \\
\hline & Nyanga & 2836 & 1123 & 2262 & H4 & $2.5: 1: 2.0$ & unknown \\
\hline & Nyanga & 1394 & 617 & 1058 & H2 & $2.2: 1: 1.7$ & unknown \\
\hline
\end{tabular}

\section{Discussion}

\section{Sampling, preparation and analysis methods}

Two different sampling approaches were used in this study: in the first campaign a large number of fuelwood samples were randomly collected, whilst in the second and third campaigns only suspected pieces were taken. It may appear somewhat surprising that none of the 86 samples tested in the first campaign showed $\mathrm{Cr}$, Cu or As levels typical of treatment, but this campaign was done without the knowledge that treated wood had characteristic appearances and can be identified by the treatment plant catalogue. Later visual inspections of fuel supplies of caterers in urban areas confirmed that 'suspect' pieces are seen infrequently.

Sampling theory warns that significant variance can be introduced during sample processing. The focus of this investigation was not a precise determination of metal concentrations in fuelwood, but rather the detection of prior CCA treatment followed by a broad categorisation (in terms of treatment levels $\mathrm{H} 2-\mathrm{H} 6$ ). As such, we did not have to pay detailed attention to the variance resulting from the sample preparation. The generation of shavings with a drill would have introduced some variance as a result of drilling to different depths - it is likely that CCA concentrations are higher closer to the surface. Further milling to a fine powder should, however, have homogenised the samples well, resulting in the $0.25-\mathrm{g}$ sample ultimately digested being sufficiently representative of its respective timber sample.

The analysis method used in this study (EPA method 3051) was performed according to the instructions and no solid residues remained. There was some experimentation with the calibration of the ICP, particularly in the first campaign, as the expected CCA concentrations were not yet known. Generally though, for digestate metal concentrations greater than $5 \mathrm{ppm}$, the error in repeat analyses was acceptable at less than $5 \%$. The standards used in the sample analysis were approved by the SABS.

\section{CCA-treated fuelwood in urban areas}

We found wood pallets, originating from adjacent light industrial areas, to be the predominant source of fuelwood amongst informal caterers in Nyanga, Khayelitsha and Langa. The samples collected during the first sampling campaign were small, lightweight samples, easily parted with by the caterer or end-user. Of 100 tested samples collected from these urban areas, only 5 samples contained CCA; these 5 had been part of 
14 purposefully selected pieces with a suspect appearance. These wood pallets are actually discarded by industries after re-use and intended for disposal, mainly by breakage as the wood is of inferior quality and breaks when overused. The pallets are not manufactured to last for long and break quickly. Significant quantities of discarded pallet wood can easily be sourced by entrepreneurs or those in need of fuelwood.

Eisler ${ }^{15}$ reported that trees from non-contaminated areas had usually less than $1 \mathrm{mg} / \mathrm{kg}$ (dry weight) of As. However, pine (Pinus silvestris) could have $22 \mathrm{mg} / \mathrm{kg}$ (fresh weight) when the soil is contaminated to $120 \mathrm{mg} / \mathrm{kg}$. It is probable that the indicative concentrations of $13.4 \pm 13.5 \mathrm{mg} / \mathrm{kg}, 5.3 \pm 5.1 \mathrm{mg} / \mathrm{kg}$ and $7.0 \pm 3.5 \mathrm{mg} / \mathrm{kg}$ of $\mathrm{Cr}$, Cu and As, respectively, obtained from Nyanga and Khayelitsha, reflect the natural background levels. Solo-Gabrielle et al. ${ }^{12}$ reported that wood with such concentrations does not result in hazardous material as defined by the regulatory criteria in the USA. However, treated wood should not be mixed with untreated wood. ${ }^{11,12}$

\section{CCA-treated fuelwood in peri-urban areas}

Of the 16 samples collected from peri-urban areas, 11 contained CCA. In Zwelethemba, Mbekweni and Kayamandi, CCA-treated wood used for fuel was reportedly sourced from materials for the construction of lowcost houses, and from fencing initially used for homes and farms that was replaced by concrete walls or metal fences. CCA-treated wood was substantially more frequently encountered in peri-urban than in urban areas.

\section{Conclusion}

Evidence was found that CCA-treated wood is being used in informal catering activities both in Cape Town townships and in peri-urban areas of the Winelands district. In city townships, the occurrence of such timber was rare (estimated to be of the order of $0.1-1 \%$ ) and could only be detected by a trained eye as it generally was old timber; even so, only 5 out of 14 suspected samples tested positive for CCA. In periurban areas, CCA-treated timber was more frequently encountered in fuel stocks (1-90\%), and clearly distinguishable by its colour and young appearance.

Given the health risks of exposure to inorganic arsenic and chromium, our findings call, on one hand, for further research to understand more precisely the absorption and health effects of exposure to such treated timber in the Cape Town region, as well as in and around other South African and African towns and cities. On the other hand, action should be taken to limit such exposure risks by introducing regulations for timber users and suppliers.

\section{Acknowledgements}

We would like to express our grateful acknowledgements to Mr Romeo from Epping 2 TPS for a factory visit, information on safe handling of CCA-treated timber and quality control information. We also thank Mrs Helen Divey and Suzanna Vasic for analytical support. We are grateful to TWOWS for a fellowship for postgraduate studies. Lastly, we are indebted to the Vice-Chancellor of the University of Cape Town for recognising the alignment of this work with the university's new strategic objectives and the associated financial support. We applaud the volunteering work of the 'caterers' working group of the Engineers Without Borders branch at the University of Cape Town, which has worked to introduce efficient wood stoves to Nyanga-based caterers alongside our research.

\section{Authors' contributions}

R.N. collected many of the samples, digested the wood samples and wrote much of the early drafts for this manuscript. S.N. developed the wood analysis methods together with R.N and collected many of the wood samples. M.A.D. provided guidance as to the health risks of exposure to copper, chromium and arsenic and contributed relevant sections to the manuscript. H.v.B. conceived and directed the project, secured the funding, helped with the interpretation of results and edited the final version of the manuscript.

\section{References}

1. Balmer M, Hancock D. Good for people can be good for business: The convergence of opportunities for delivering basic energy to low-income households in developing countries. J Energy South Afr. 2009;20(2):10-16.

2. Nissing C, Von Blottnitz H. A material flow analysis of wood and paper in Cape Town: Is there potential to redirect flows in formal and informal sectors to foster use as a renewable source? Int J Env Sustain Dev. 2007;6(2):147-156. http://dx.doi.org/10.1504/IJESD.2007.014199

3. Nissing C, Von Blottnitz $H$. Renewable energy for sustainable urban development: Redefining the concept of energisation. Energ Policy. 2010;38:2179-2187.

4. Dart RC. Medical toxicology. Philadelphia, PA: Williams \& Wilkins, 2004; p. 1393-1401.

5. Chou S, Harper C, Ingerman L, et al. Toxicological profile for arsenic. Atlanta, GA: US Department of Health and Human Services, Public Health Service, Agency for Toxic Substances and Disease Registry; 2007.

6. Ministry of the Environment (MOE). Copper in the environment. Ontario Fact Sheet. Ontario: MOE; 2001

7. Maas RP, Patch SC, Berkowitz JF. Integrated studies of the dynamics of arsenic release and exposure from CCA-treated lumber. Environmental Impacts of Preservative-Treated Wood Conference; 2004 Feb 8-11. Orlando, Florida. Gainesville, FL: Florida Center for Environmental Solutions. p. 17-31.

8. Martin R. Arsenic and CCA treated wood. This Old House Magazine. 1998 March/April;118-125.

9. Solo-Gabrielle HM, Townsend TG, Cais Y. Environmental impacts of CCAtreated wood within Florida, USA. Environmental Impacts of PreservativeTreated Wood Conference; 2004 Feb 8-11; Orlando, Florida. Gainesville, FL: Florida Center for Environmental Solutions. p. 57-70.

10. Lebow S. Alternatives to chromated copper arsenate (CCA) for residential construction. Environmental Impacts of Preservative-Treated Wood Conference; 2004 Feb 8-11; Orlando, Florida. Gainesville, FL: Florida Center for Environmental Solutions. p. 156-168.

11. Khan BI, Solo-Gabrielle HM, Dubey BK, Townsend TG, Cai Y. Arsenic speciation of solvent-extracted leachate from new and weathered CCAtreated wood. Environ Sci Technol. 2004;38:4527-4534. http://dx.doi. org/10.1021/es049598r

12. Solo-Gabrielle HM, Townsend TG, Mesick B, Calitu V. Characteristics of chromated copper arsenate-treated wood ash. J Hazard Mater. 2002;B89:213-232. http://dx.doi.org/10.1016/S0304-3894(01)00311-9

13. Stilwell D, Toner M, Sawhney B. Dislodgeable copper, chrome and arsenic from CCA-treated wood surfaces. Sci Total Environ. 2003;312(1-3):123131. http://dx.doi.org/10.1016/S0048-9697(03)00195-5

14. Rogers JM, Stewart M, Petrie JG, Haynes BS. Deportment and management of metals produced during combustion of CCA-treated timbers. J Hazard Mater. 2007;A139:500-505.

15. Eisler R. Arsenic hazards to fish, wildlife, and invertebrates: A synoptic review. Contaminant Hazard Reviews Report No. 12. Laurel, MD: Patuxent Wildlife Research Center, US Fish and Wildlife Service; 1988. 